\title{
Service Quality in Public Sector Internet Banking Services in Erode City
}

\author{
K. S. Eswari ${ }^{{ }^{*}}$ and S. Jamunadevi ${ }^{2}$ \\ 'Associate Professor and Head, PG \& Research Department of Commerce, Vellalar College for Women, Erode, India; \\ drkseswari@gmail.com \\ ${ }^{2}$ Assistant Professor, PG \& Research Department of Commerce, Vellalar College for Women, Erode, India; \\ jamuna023@gmail.com
}

\begin{abstract}
Probing the quality of service sector has gained momentum and in particular the banking sector is the main focus of attention for its quality of e-services. This study is based on E-SERVQUAL scale based on gap model proposed by Parasuraman, Zeithaml and Arvind Malhotra [3, 4]. A sample size of 200 was taken using convenience sampling method covering five public sector banks in Erode city. The study reveals that the internet banking services lag behind the customers' anticipation. This is confirmed by the negative gap registered in case of all the parameters of evaluation of e-service quality, which affirms the findings of the earlier researchers [5, 7, 10-13]. Therefore, narrowing down this gap is the need of the hour to elevate the internet banking services offered by the select banks yielding a buoyant e-banking segment.
\end{abstract}

Keywords: E-SERVQUAL, Expectations, Internet Banking, Perception

\section{Introduction}

In the era of ambitious internet banking, offering excellent and desirable quality service electronically is indispensable to remain in the fray. To continue to earn the patronage of customers and to turn on all potential into actual, its calls for rendering exhaustive service that are noticeably better than others [1]. Hence, this paper investigates the quality of internet banking services rendered by public sector banks in Erode city, based on E-SQ developed by Parasuraman, Zeithaml and Arvind Malhotra [3, 4].

\section{Review of Literature}

Zeithaml [2] focused on measuring the service quality of web based services and found that demographic, behaviour and experience also affect E-SQ, therefore divided E-SQ into two scales; E-SQ core scale and recovery scale. Parasuraman, Zeithaml and Arvind Malhotra $[3,4]$ disclosed that two different scales were necessary for capturing electronic service quality.

Sudesh [5] confirmed the inferior services of the public sector banks. Divya Singhal and Padhmanabhan [6] indicated that 'utility request', 'security', 'utility transaction', 'ticket booking' and 'fund transfer' are the major factors influencing the use of internet banking. Mohamed Sadique Khan [7] probed the e-banking services in our country revealing the dissatisfaction of the customer in respect of 'user friendliness'. Arash Shahin and Moireh Samea [8] yielded a superior model over conventional models to evaluate the service quality and gaps. Santhiyavalli [9] has asserted the contributors to satisfaction of the customers towards the services of SBI. Rama Mohana Rao [10] disclosed the perceptual variance of the customer towards the services of private and public sector banks. Agha Tahir Ijaz and Asghar Ali [11] concluded that in the fierce and changing ambiance

*Author for correspondence 
the banks in Pakistan need to give a fillip to augment the service quality disposition for continued existence. Lokanadha Reddy and Shaik Karim [12] brought to fore the student customers' satisfaction level towards banking services as moderate only due to quality gaps. Saravanan and Haja Mohideen [13] claimed the necessity to establish an effective feedback system to sense the anticipation of the customers for rendering better service quality in banks at Pudhucherry.

The present study exposes the quality of e-services of select public sector banks in Erode city.

\section{Statement of the Problem}

Banking is customer oriented service industry and therefore providing better service to customer is the main motive of every bank. Traditional banking operations are limited and allow limited times to customer for banking activities. The technological advancements have changed the banks to remain fully based on computerization; connect to their services not only at the local level but also at the international level. Internet banking provides new opportunities for banks to expand and yield many benefits to customers and also flexibility in operations. The internet banking has made the customer say goodbye to limited time banking and local area operations. Due to the huge benefits, most of the customers use internet banking services.

Hence, the study seeks to provide answer to the following:

- The magnitude of internet banking in fulfilling the customer expectation.

- The deviation between the customers' contemplated and comprehended service quality of internet banking.

\section{Objectives}

The specific objectives are as follows:

- To bring out a description of the respondents.

- To measure the magnitude of perception and expectation of customers on service quality of internet banking and the divergence between the same.

\section{Scope}

The study is specific with reference to the five public sector banks chosen for investigation which included SBI, BOB, Canara Bank, IOB and Indian Bank.

\section{Methodology}

\subsection{Sample Size and Sampling Technique}

Five public sector banks are purposively selected for the study. Among these five banks, a sample of 200 customers of Erode city was selected based on convenient sampling.

\subsection{Sources of Data}

Both primary and secondary data were employed.

\subsection{Tools of Analysis}

The statistical tools such as, simple percentage, mean, ' $\mathrm{t}$ ' test and gap score were used for the purpose of this study.

\section{Results and Discussion}

\subsection{Profile of the Respondents}

From Table 1, it is clear that $40 \%$ are of the age of below 30 years, $63 \%$ are male, $67 \%$ are unmarried, $38 \%$ are under graduates, $41 \%$ are employed, $38.5 \%$ earned monthly income between Rs. 20001 to Rs.30000, 64\% represent 3 to 5 members in their family and $41 \%$ are residing at semi urban area.

The bank account detail of the respondents reveals that $82 \%$ are having savings account, $52 \%$ are holding account in bank for $4-8$ years, and $33 \%$ are using internet banking for less than 4 times in a month.

\subsection{Analysis of Customer Expected and Perceived Service Quality of the Internet Banking}

Following null hypothesis is framed and tested to know the significance of the service quality gap. 
$\mathrm{H}_{0}$ : Expected and perceived service quality does not differ significantly.

Table 2 indicates that the mean values of expectation are higher than the perception of the customer in the case of all the dimensions and also of overall values of all dimensions. Further to prove this statistically, ' $t$ ' values are calculated for all the dimensions. The calculated value of ' $t$ ' exceeds the table value at $1 \%$ level rejecting the $\mathrm{H}_{0}$. Hence, the internet banking services in public sector banks have not lived up to the expectation of customers can be inferred.

\subsection{Results of Mean Gap Score}

Table 3 discloses the overall mean difference of service quality dimensions as 1.314. The gap score of reliability, accessibility, ease of navigation, privacy/ security are less than the overall score indicating a smaller gap which means a lower dissatisfaction of customers. The gap score of efficiency, responsiveness, and fulfillment are more than the overall score and hence show a higher gap between expectation and perception, which means a far more customer dissatisfaction regarding these services.

\subsection{Result of E-SERVQUAL Scores by Dimensions for Internet Banking in Public Sector Banks}

Table 4 shows that the customers' expectation exceeds their perception in respect of all dimensions and overall service quality score with respect to the select banks' e-services. Of the seven dimensions, expectation is at the highest (19.65) for privacy/ security dimensions that covers the issue of individual attention. Expectation is at the lowest (7.25) for fulfillment. On other hand, the perception is at the highest (14.64) in case of privacy/ security dimensions and the second highest perception (14.36) is with respect to ease of navigation followed by 12.36 for reliability and responsiveness, 12.25 for accessibility, 12.23 for efficiency and 3.74 for fulfillment.

Table 1. Respondents' Description

\begin{tabular}{|c|c|c|c|c|}
\hline S.No. & & ables & No. of & $\%$ \\
\hline 1 & Age & $\begin{array}{l}\text { Up to } 30 \text { years } \\
\quad 31-40 \\
41-50 \\
\text { Above } 50 \text { years }\end{array}$ & $\begin{array}{l}80 \\
69 \\
28 \\
23\end{array}$ & $\begin{array}{c}40 \\
34.5 \\
14 \\
11.5\end{array}$ \\
\hline 2 & Gender & $\begin{array}{c}\text { Male } \\
\text { Female }\end{array}$ & $\begin{array}{c}126 \\
74\end{array}$ & $\begin{array}{l}63 \\
37\end{array}$ \\
\hline 3 & Marital Status & $\begin{array}{c}\text { Married } \\
\text { Unmarried }\end{array}$ & $\begin{array}{c}134 \\
66\end{array}$ & $\begin{array}{l}67 \\
33\end{array}$ \\
\hline 4 & Formal education & $\begin{array}{c}\text { Up to school level } \\
\text { Graduate } \\
\text { Post Graduate } \\
\text { Professional Degree }\end{array}$ & $\begin{array}{l}22 \\
76 \\
64 \\
38\end{array}$ & $\begin{array}{l}11 \\
38 \\
32 \\
19\end{array}$ \\
\hline
\end{tabular}




\begin{tabular}{|c|c|c|c|c|}
\hline 5 & $\begin{array}{l}\text { Occupational } \\
\text { Status }\end{array}$ & $\begin{array}{c}\text { Student } \\
\text { Employee } \\
\text { Business } \\
\text { Professional } \\
\text { Others }\end{array}$ & $\begin{array}{c}17 \\
82 \\
55 \\
38 \\
8\end{array}$ & $\begin{array}{c}85 \\
41 \\
27.5 \\
19 \\
4\end{array}$ \\
\hline 6 & $\begin{array}{l}\text { Monthly Family } \\
\text { Income }\end{array}$ & $\begin{array}{c}\text { Below ₹ } 20,000 \\
20,001-₹ 30,000 \\
30,001-₹ 40,000 \\
\text { Above ₹ 40,000 }\end{array}$ & $\begin{array}{l}27 \\
77 \\
58 \\
38\end{array}$ & $\begin{array}{c}13.5 \\
38.5 \\
29 \\
19\end{array}$ \\
\hline 7 & Size of the Family & $\begin{array}{l}\text { Upto } 2 \text { members } \\
\text { 3-5 members } \\
6 \text { members \& above }\end{array}$ & $\begin{array}{c}30 \\
128 \\
42\end{array}$ & $\begin{array}{l}15 \\
64 \\
21\end{array}$ \\
\hline 8 & Area of Residence & $\begin{array}{c}\text { Rural } \\
\text { Semi-urban } \\
\text { Urban }\end{array}$ & $\begin{array}{l}44 \\
82 \\
74\end{array}$ & $\begin{array}{l}22 \\
41 \\
37\end{array}$ \\
\hline 9 & Type of Account & $\begin{array}{l}\text { Current Account } \\
\text { Savings account }\end{array}$ & $\begin{array}{c}36 \\
164\end{array}$ & $\begin{array}{l}18 \\
82\end{array}$ \\
\hline 10 & $\begin{array}{l}\text { Period of holding } \\
\text { Account }\end{array}$ & $\begin{array}{l}\text { Short (Less than } 3 \text { years) } \\
\text { Moderate ( } 4-8 \text { years) } \\
\text { Long (More than } 8 \text { years) }\end{array}$ & $\begin{array}{c}58 \\
104 \\
38\end{array}$ & $\begin{array}{l}29 \\
52 \\
19\end{array}$ \\
\hline 11 & $\begin{array}{l}\text { Period of using } \\
\text { internet banking }\end{array}$ & $\begin{array}{l}\text { Short (Less than } 1 \text { year) } \\
\text { Moderate ( } 1-4 \text { years) } \\
\text { Long (Above } 4 \text { years) }\end{array}$ & $\begin{array}{c}26 \\
110 \\
64\end{array}$ & $\begin{array}{l}13 \\
55 \\
32\end{array}$ \\
\hline 12 & Frequency of use & $\begin{array}{l}\text { Occasionally } \\
\text { Less than } 2 \text { times } \\
\text { Less than } 4 \text { times } \\
\text { More than } 4 \text { times }\end{array}$ & $\begin{array}{l}28 \\
60 \\
66 \\
46\end{array}$ & $\begin{array}{l}14 \\
30 \\
33 \\
23\end{array}$ \\
\hline
\end{tabular}

Source: Primary data 
Table 2. Mean Scores of Expected and Perceived Service Quality

\begin{tabular}{|c|c|c|c|c|c|c|c|}
\hline $\begin{array}{c}\text { Dimensions } \\
{[3,4,7]}\end{array}$ & Service Quality & $\begin{array}{l}\text { Mean } \\
\text { Scores }\end{array}$ & $\begin{array}{c}\text { Std. } \\
\text { deviation }\end{array}$ & Std. Error & 't' value & df & Result \\
\hline \multirow{2}{*}{ Reliability } & Expectation & 16.595 & 2.338 & 0.165 & \multirow{2}{*}{2.64} & \multirow{2}{*}{199} & \multirow{2}{*}{ Significant } \\
\hline & Perception & 12.36 & 2.269 & 0.160 & & & \\
\hline \multirow{2}{*}{ Accessibility } & Expectation & 16.9 & 2.910 & 0.206 & \multirow{2}{*}{3.464} & \multirow{2}{*}{199} & \multirow{2}{*}{ Significant } \\
\hline & Perception & 12.25 & 3.043 & 0.215 & & & \\
\hline \multirow{2}{*}{ Ease of navigation } & Expectation & 19.19 & 3.264 & 0.231 & \multirow{2}{*}{3.036} & \multirow{2}{*}{199} & \multirow{2}{*}{ Significant } \\
\hline & Perception & 14.36 & 2.474 & 0.175 & & & \\
\hline \multirow{2}{*}{ Privacy/Security } & Expectation & 19.65 & 2.434 & 0.172 & \multirow{2}{*}{4.085} & \multirow{2}{*}{199} & \multirow{2}{*}{ Significant } \\
\hline & Perception & 14.64 & 3.203 & 0.226 & & & \\
\hline \multirow{2}{*}{ Efficiency } & Expectation & 18.2 & 2.457 & 0.174 & \multirow{2}{*}{3.29} & \multirow{2}{*}{199} & \multirow{2}{*}{ Significant } \\
\hline & Perception & 12.23 & 3.034 & 0.215 & & & \\
\hline \multirow{2}{*}{ Responsiveness } & Expectation & 18.28 & 2.958 & 0.209 & \multirow{2}{*}{3.640} & \multirow{2}{*}{199} & \multirow{2}{*}{ Significant } \\
\hline & Perception & 12.36 & 2.520 & 0.178 & & & \\
\hline \multirow{2}{*}{ Fulfillment } & Expectation & 7.25 & 3.16 & 0.341 & \multirow{2}{*}{3.674} & \multirow{2}{*}{199} & \multirow{2}{*}{ Significant } \\
\hline & Perception & 3.74 & 3.26 & 0.306 & & & \\
\hline \multirow{2}{*}{ Overall dimensions } & Expectation & 116.10 & 14.52 & 0.968 & \multirow{2}{*}{7.26} & \multirow{2}{*}{199} & \multirow{2}{*}{ Significant } \\
\hline & Perception & 81.94 & 13.28 & 0.939 & & & \\
\hline
\end{tabular}

Source: Primary data

Significant at $1 \%$ level of significance 
Table 3. Mean Score Analysis and Gap between the Perception and Expectation of Internet Banking

\begin{tabular}{|c|c|c|c|c|}
\hline $\begin{array}{l}\text { Service Quality Dimensions } \\
\qquad[3,4,7]\end{array}$ & $\mathbf{P}$ & $\mathrm{E}$ & $\begin{array}{l}\text { Mean Difference of each } \\
\text { statement }(\mathrm{P}-\mathrm{E})\end{array}$ & $\begin{array}{c}\text { Mean difference for each service } \\
\text { quality dimensions }\end{array}$ \\
\hline \multicolumn{5}{|c|}{ Reliability } \\
\hline Statement 1 & 3.93 & 5 & -1.075 & \multirow{4}{*}{1.0613} \\
\hline Statement 2 & 2.9 & 4.025 & -1.125 & \\
\hline Statement 3 & 2.43 & 3.52 & -1.095 & \\
\hline Statement 4 & 3.1 & 4.05 & -0.95 & \\
\hline \multicolumn{5}{|c|}{ Accessibility } \\
\hline Statement 5 & 3.29 & 4.32 & -1.025 & \multirow{4}{*}{1.1625} \\
\hline Statement 6 & 3.34 & 4.50 & -1.16 & \\
\hline Statement 7 & 2.85 & 3.98 & -1.13 & \\
\hline Statement 8 & 2.77 & 4.10 & -1.335 & \\
\hline \multicolumn{5}{|c|}{ Ease of navigation } \\
\hline Statement 9 & 3.53 & 4.82 & -1.295 & \multirow{4}{*}{1.2113} \\
\hline Statement 10 & 3.43 & 4.78 & -1.35 & \\
\hline Statement 11 & 3.54 & 4.81 & -1.275 & \\
\hline Statement 12 & 3.86 & 4.78 & -0.925 & \\
\hline \multicolumn{5}{|c|}{ Privacy /Security } \\
\hline Statement 13 & 4.035 & 4.93 & -0.895 & \multirow{4}{*}{1.2538} \\
\hline Statement 14 & 3.515 & 4.81 & -1.295 & \\
\hline Statement 15 & 3.35 & 4.90 & -1.55 & \\
\hline Statement 16 & 3.74 & 5.01 & -1.275 & \\
\hline \multicolumn{5}{|c|}{ Efficiency } \\
\hline Statement 17 & 3.23 & 4.87 & -1.64 & \multirow{4}{*}{1.4938} \\
\hline Statement 18 & 2.68 & 4.35 & -1.67 & \\
\hline Statement 19 & 2.93 & 4.48 & -1.55 & \\
\hline Statement 20 & 3.39 & 4.50 & -1.115 & \\
\hline \multicolumn{5}{|c|}{ Responsiveness } \\
\hline Statement 21 & 3.16 & 4.88 & -1.72 & \multirow{4}{*}{1.48} \\
\hline Statement 22 & 2.095 & 4.45 & -1.545 & \\
\hline Statement 23 & 3.385 & 4.49 & -1.105 & \\
\hline Statement 24 & 2.91 & 4.46 & -1.55 & \\
\hline \multicolumn{5}{|c|}{ Fulfillment } \\
\hline Statement 25 & 1.54 & 3.25 & -1.71 & \multirow[b]{2}{*}{1.455} \\
\hline Statement 26 & 2.2 & 4 & -1.8 & \\
\hline Overall dimensions & 81.94 & 116.10 & -34.16 & 1.314 \\
\hline
\end{tabular}

Source: Primary data 
Table 4. SERVQUAL Scores by Dimensions for Internet Banking in Public Sector Banks

\begin{tabular}{|c|c|c|c|}
\hline $\begin{array}{c}\text { Dimensions } \\
{[3,4,7]}\end{array}$ & $\begin{array}{c}\text { Mean value of Perception } \\
\text { scores }\end{array}$ & $\begin{array}{c}\text { Mean value of } \\
\text { Expectation scores }\end{array}$ & Difference (P-E) \\
\hline Reliability & 12.36 & 16.595 & 4.245 \\
\hline Accessibility & 12.25 & 16.9 & 4.65 \\
\hline Ease of navigation & 14.36 & 19.19 & 4.84 \\
\hline Privacy /Security & 14.64 & 19.65 & 5.015 \\
\hline Efficiency & 12.23 & 18.2 & 5.97 \\
\hline Responsiveness & 12.36 & 18.28 & 5.92 \\
\hline Fulfillment & 3.74 & 7.25 & 3.51 \\
\hline Overall service quality index & 81.94 & 116.10 & 34.16 \\
\hline
\end{tabular}

Source: Primary data

\section{Key Findings}

The above analysis has divulged the following key findings:

- The select banks have not lived up to the expectations of customers in providing internet banking services.

- Negative E-SERVQUAL scores across all the dimensions of evaluation reveal the scope for improving the quality of internet banking by the select banks.

- The banks should take right action to avoid the customers moving to private sector banks for better services and attractive schemes compared to public sector banks.

\section{Conclusion}

The study reveals that the select public sector banks' internet banking services lag behind the customers' anticipation. This is confirmed by the negative gap registered in case of all the parameters of evaluation of e-service quality, which affirms the findings of the earlier researchers [5, 7, 10-13]. Therefore, narrowing down this gap is the need of the hour to elevate the internet banking services offered by the select banks yielding a buoyant e-banking segment.

\section{References}

1. Available: http://www.academia.edu/6518168/Production_ Management_Project

2. Zeithaml V., "Service Excellence in Electronic Channel", Managing Service Quality: an international journal, vol. 12(3), pp. 135-138, 2002.

3. Parasuraman A., Zeithaml V., Malhotra A., "Service Quality Delivery through Web Sites: A Critical Review of Extant Knowledge", Journal of the Academy of Marketing Science, Vol. 30(4), pp. 362-375, 2002.

4. Parasuraman A., Zeithaml V., Malhotra A., "E-S-QUAL, A Multiple-Item Scale for Assessing Electronic Service Quality", Journal of Service Research, vol. 7(3), pp. 213-233, 2005.

5. Sudesh, "Service quality in banks- A study in Haryana and Chandigarh", NICE Journal of Business, vol. 2(1), pp. 55-65, 2007.

6. Singhal D., Padhmanabhan V., "A study on customer perception towards internet banking: identifying major contributing factors", The journal of Nepalese business studies, vol. 1, pp. 101-111, 2008 Dec.

7. Khan M.S., "Service quality evaluation in internet banking", International Journal of Indian Culture and Business Management, Vol. 2(1), pp. 30-46, 2009. 
8. Shahin A., Samea M., "Developing the Models of Service Quality Gaps: A Critical Discussion”, Journal of Business Management and Strategy,Vol. 1(1), pp. 1-11, 2010. Available: www.macrothink.org/bms

9. Santhiyavalli G., "Customer's perception of service quality of State Bank of India - A Factor Analysis", IJMBS, Vol. 1(3), pp. 78-84, 2011 Sep.

10. Rao R.M.K., "Service Quality Perceptions of Customers: A Study of the Customers' of Public Sector and Private Sector Commercial Banks in India”, International Journal of Research in Commerce \& Management, vol. 2(11), pp. 60-71, 2011 Nov.
11. Ijaz A.T., Ali A., "Measuring Banks Service Attitude: An approach to employee and customer Acuities", IOSR Journal of Business and Management, vol. 7(2), pp. 60-66, 2013 Jan-Feb. Available: www.iosrjournals.org.

12. Reddy L., Karim S., "A Study on Students Perception towards Quality of Banking Services", IOSR Journal of Business and Management, vol. 16(8), pp. 37-41, 2014 Aug. Available: www.iosrjournals.org

13. Saravanan., Mohideen H., "Customers' Evaluation of Service Quality in Banking Sector at Pondicherry", International Journal of Marketing Research Review, vol. 3(6), pp. 13-17, 2015 Jun. Available: www.icmrr.org 